\title{
BDNF wt Allele
}

National Cancer Institute

\section{Source}

National Cancer Institute. BDNF wt Allele. NCI Thesaurus. Code C51417.

Human BDNF wild-type allele is located in the vicinity of $11 \mathrm{p} 14.1$ and is approximately 67

$\mathrm{kb}$ in length. This allele, which encodes brain-derived neurotrophic factor protein, is

involved in both stress response regulation and in the survival of striatal neurons.

Expression of the allele is decreased in both Alzheimer's and Huntington disease. 